\title{
Emotional Intelligence Level Higher in Residents Who Took a Gap Year Before Medical School [Letter]
}

This article was published in the following Dove Press journal: Advances in Medical Education and Practice

\section{Tun Tha (D)}

School of Medicine, Barts and the London School of Medicine and Dentistry, Queen Mary University of London, London, UK
Correspondence: Tun Tha Tel +44 7449505477

Email t.z.tha@smdI5.qmul.ac.uk

\section{Dear editor}

I read with great interest the study by Shahid et $\mathrm{al}^{1}{ }^{1}$ which investigated the effect of taking time off training, including undertaking a gap year, on levels of emotional intelligence (EI) in American resident physicians. The authors should be thanked and congratulated for improving the understanding of a fundamental aspect of personal and professional development during one's career as a doctor. I would like to put forward some comments regarding this study.

The main finding that residents who took time off training had higher overall EI scores compared to those who had not (mean EI 103.96 vs 99.52, respectively) was statistically significant $(\mathrm{p}=0.02)$, but I question whether this difference has considerable significance in real world practice. The overall difference itself is arguably marginal when interpreting the EI scores on the Bar-On Emotional Quotient Inventory 2.0 (EQ-i 2.0®) scale; the majority of scores from both groups fall in the same "average EQ" category (EQ 90-110). ${ }^{2}$ This is also apparent when interpreting individual composite scores. Moreover, it could be difficult to observe any of these differences in actuality as Bar-On's EQ-i reflects potential for emotional performance rather than true performance itself and is process-based. ${ }^{3}$ The Mayer-Salovey- Caruso Emotional Intelligence Test (MSCEIT) would have been a viable alternative to measure EI in that it is ability- and outcome-based.

The study's cross-sectional design only provided a snapshot of EI, as acknowledged by the authors, this limited any finding of causality. It would be valuable to discern whether EI scores actually improve after taking time off, as this is more fitting with the concept that EI is dynamic; this could be achieved via a cohort study with EI scores tested before and after time off training.

The EQ-i 2.0 instrument used wholly relies on participant self-assessment, ${ }^{2}$ as such this is likely to have produced social desirability response bias whereby residents may have deliberately over- and underestimated responses. Furthermore, the study's low response rate $(36.2 \%)$ could have incurred substantial sampling bias. Willingness to participate in the survey could have been in itself associated with greater selfperception, self-expression and happiness, all being composites of EQ-i 2.0.

It was good that study also examined the effect of other variables on EI including age, sex, degree type and speciality. However, there are more variables that could have been investigated such as physical and mental health, socioeconomic status, marital 
status and drug use; some of which have been shown to affect EI and hence may have potentially acted as confounders. ${ }^{4,5}$ Notably, results on the effect of age on EI were not explicitly included; it would be interesting to glean if the effect of agerelated emotional maturation was at play in the study.

Finally, I agree with the authors' conclusion that undertaking a gap year may be seen as favourable in residency applications in that it may hone EI. However, it is important to also emphasise that EI can be developed and fostered through offering educational interventions, mentoring and counselling to future doctors.

\section{Disclosure}

The author reports no conflicts of interest in this communication.

\section{References}

1. Shahid R, Adams W. Emotional intelligence level higher in residents who took a gap year before medical school. Adv Med Educ Pract. 2020;11:559-562. doi:10.2147/AMEP.S268464

2. Bar-On R. Emotional Quotient Inventory 2.0 User's Handbook. Toronto Canada: Multi- Health Systems; 2004.

3. O'Connor PJ, Hill A, Kaya M, Martin B. The measurement of emotional intelligence: a critical review of the literature and recommendations for researchers and practitioners. Front Psychol. 2019;10:1116. doi:10.3389/fpsyg.2019.01116

4. Tsaousis I, Nikolaou I. Exploring the relationship of emotional intelligence with physical and psychological health functioning. Stress Health. 2005;21(2):77-86. doi:10.1002/smi.1042

5. Joseph N, Panicker V, Nelliyanil M, Jindal A, Viveki R. Assessment and determinants of emotional intelligence and perceived stress among students of a medical college in south India. Indian J Public Health. 2015;59(4):310-313. doi:10.4103/0019-557X.169666

Dove Medical Press encourages responsible, free and frank academic debate. The content of the Advances in Medical Education and Practice 'letters to the editor' section does not necessarily represent the views of Dove Medical Press, its officers, agents, employees, related entities or the Advances in Medical Education and Practice editors. While all reasonable steps have been taken to confirm the content of each letter, Dove Medical Press accepts no liability in respect of the content of any letter, nor is it responsible for the content and accuracy of any letter to the editor.

\section{Publish your work in this journal}

Advances in Medical Education and Practice is an international, peerreviewed, open access journal that aims to present and publish research on Medical Education covering medical, dental, nursing and allied health care professional education. The journal covers undergraduate education, postgraduate training and continuing medical education including emerging trends and innovative models linking education, research, and health care services. The manuscript management system is completely online and includes a very quick and fair peer-review system. Visit http://www.dovepress.com/testimonials.php to read real quotes from published authors. 